\author{
Mert Ural
}

\title{
Risk management for sustainable tourism
}

\section{DOI 10.1515/ejthr-2016-0007}

received December 10, 2014; accepted April 2, 2015

\begin{abstract}
The world tourism industry suffered some severe losses as a result of a series of major international events and the magnitude of disaster/catastrophic risks has become a major topic of discussion for a sustainable tourism especially in the insurance industry. Risk management in the tourism context refers to the planning and implementation of processes directed towards managing the adverse effects of crises and disasters/catastrophes on tourism. The sustainability of a tourism destination is significantly influenced by its ability to adapt to changing market conditions, use resources efficiently and deliver innovative planning and development strategies about risk management. The aim of this paper is to consider the key elements of crises and disasters and their effects upon tourism destinations, and to provide background on risk management processes for sustainable tourism.
\end{abstract}

Keywords: Disasters, Catastrophes, Risk Management, Tourism, Sustainability.

\section{Introduction}

The influence of environmental conditions (hazards, disasters and catastrophes) on global patterns of economic development is the subject of especially the 21th century, primarily because identifying these causal effects is challenging. Unlike relatively rare financial crises, political crises, and civil wars, disasters occur regularly/irregularly and repeatedly. The increasing incidence and intensity of natural disasters and climate change have a distinct

*Corresponding author: Mert Ural, Dokuz Eylül University, Faculty of Economics and Administrative Sciences, Department of Economics 35160 Buca, Izmir, TURKEY, Phone: 0090232 3010633, E-mail: mert. ural@deu.edu.tr

This paper has been presented at the ITC'14 -VII. International Tourism Congress: The Image and Sustainability of Tourist Destinations held in Sultan Qaboos University, Muscat, Sultanate of Oman, December 02-04, 2014. impact on the environment and vice versa and must therefore be seen as an integrated whole.

Countries face a wide range of disasters and crises from natural, technological, biological and civil/political hazards. Even a hazard impact will not necessarily produce a disaster. If an earthquake were to occur in a distant and unpopulated area and cause no harm to people or damage to facilities, it would not be a disaster. Catastrophe is defined as a sudden and widespread disaster, which results in extraordinary levels of mass casualties, damage, or disruption severely affecting the population, environment and/or economy.

Catastrophes occur infrequently; within this broad classification we can divide frequency even further, into non-repetitive, irregular, regular, and seasonal events as can be seen on Figure 1 (Banks 2005: 7-8). Catastrophic risk is even harder to manage, because its relative infrequency makes it difficult to measure.

Risks in the environmental category include both natural disasters/catastrophes (tropical cyclones, tornadoes, hurricanes, typhoons, floods, frosts, droughts, landslides, earthquakes, tsunamis, volcanoes, lahar, erosion, epidemics, plagues) and man-made risks (industrial accidents, transport accidents, crime, terrorism, political conflict, structure failures, structure fire, contamination) (Granger 2000: 25; Swiss Re 2014: 45; World Economic Forum 2014: 12; Hsiang and Jina 2014). Earthquakes, tropical cyclones, and flooding account for approximately 90\% of all catastrophic economic losses (Banks 2005: 18). Disasters affect countries' tourism and growth in the long-run.

Disasters cannot be prevented with existing science and technology, but the losses they may inflict and the impact on individuals, industries and governments can be reduced with disaster risk management programs. Therefore, determining how to realize tourism disaster risk identification, evaluation, control and transfer with appropriate disaster risk management tools, and establishing a disaster risk and loss evaluation model unique to the tourism industry, are extremely important and urgent tasks (Tsai 2013: 932; Lynham and Page 2012).

The purpose of this study is to consider the key elements of crises and disasters and their effects upon tourism destinations, and to emphasize the importance of 


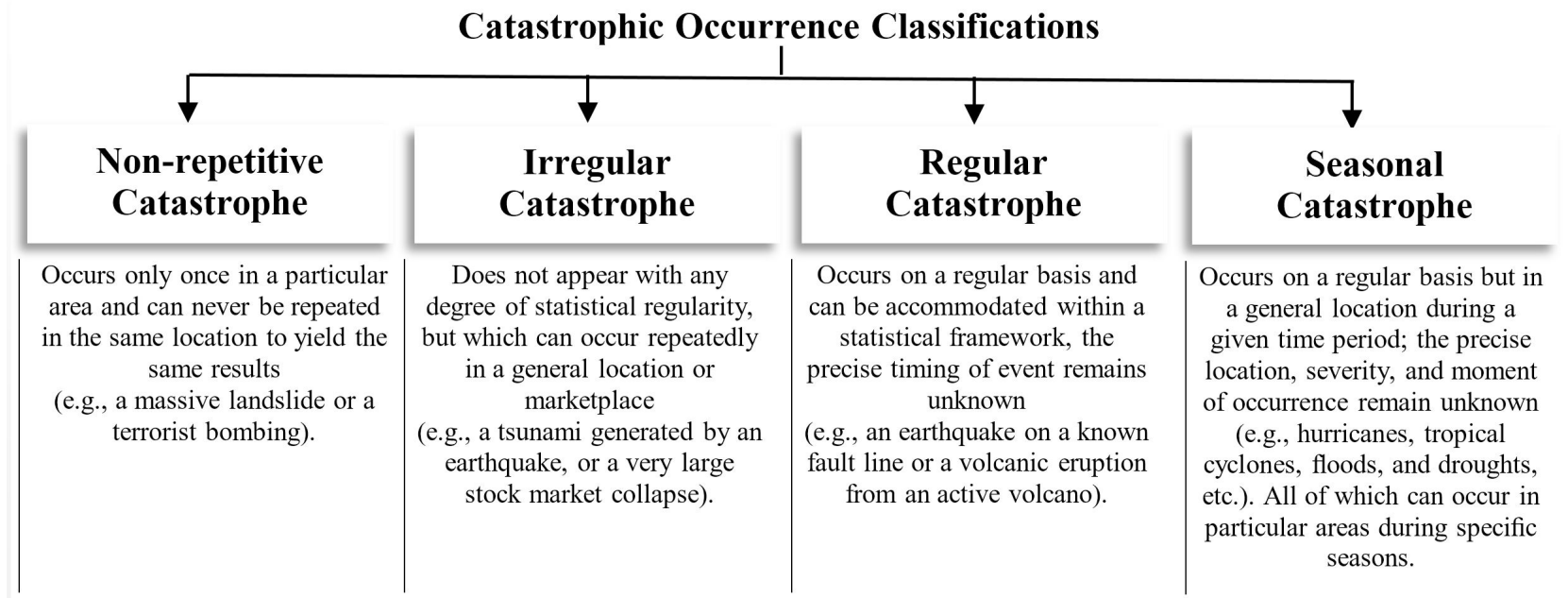

Figure 1: Catastrophic occurrence classifications

risk management processes for sustainable tourism. The remainder of this paper proceeds as follows. In section 2 details the economics of disasters and sustainability of tourism. Section 3 treats insurance and the risk management framework in tourism industry. Section 4 describes the tourism risk management process and lastly, Section 5 contains some concluding remarks for further discussions.

\section{The economics of disasters and sustainability of tourism}

During the 21th century, the losses from disasters/catastrophes have expanded dramatically in many developed and developing countries. The trend towards increasing losses is on the rise, making active risk management more essential than ever (Banks 2005: 13). Disasters are often labeled low-frequency (probability)/high-severity events.

The notion that natural disasters might have permanent long-run effects on income is not obvious, in part because these events elicit economic responses fundamentally different from man-made macroeconomic disasters (e.g. currency or banking crises). Skidmore and Toya (2002) argues that disasters may temporarily stimulate economies to grow faster because demand for goods and services increase as populations replace lost capital. Cuaresma, Hlouskova and Obersteiner (2008), and Hallegatte and Dumas (2009) argues that growth may suffer initially, since lives may be lost and productive capital destroyed. Yang (2008) argues that growth should suffer for a finite period, but that it should eventually rebound because the marginal product of capital will rise to abnormally high levels, causing income levels to converge back to their pre-disaster trend. Anttila-Hughes and Hsiang (2011) argues that disasters lead slow growthbut no rebound occurs because the various recovery mechanisms above fail to outweigh the direct negative effect of losing capital. According to this hypothesis, post-disaster output may continue to grow in the long run, but permanently lower than its pre-disaster trajectory.

Travel and tourism -encompassing accommodation, transport, and catering, recreation and visitor servicesis one of the driving forces of economic development in developed and developing countries (Robertson, Kean and Moore 2006: 6-7). According to the United Nations World Tourism Organization, over the past six decades, tourism has experienced continued growth and diversification to become one of the largest and fastest growing economic sectors in the world (WTTC 2010). Over time, an increasing number of destinations have opened up and invested in tourism development, turning modern tourism into a key driver for socioeconomic progress.

The global travel and tourism industry generates several thousand billion U.S. dollars in revenue each year as seen on Figure 2. The statistic shows the direct and total economic impact of travel and tourism on the global economy from 2006 to 2013. In 2013, while the direct contribution of travel and tourism was 2,155 billion U.S. dollars, the total contribution was 6,990 billion U.S. dollar. The figures for total contribution also include indirect and induced contributions which includes accommodation services, food and beverage services, retail trade, transportation services and cultural, sports and recreational services.

The World Travel and Tourism Council (WTTC 2014: 7) provides a snapshot of the projected value of tourism to the world's economy from 2013 to 2024 . The total 


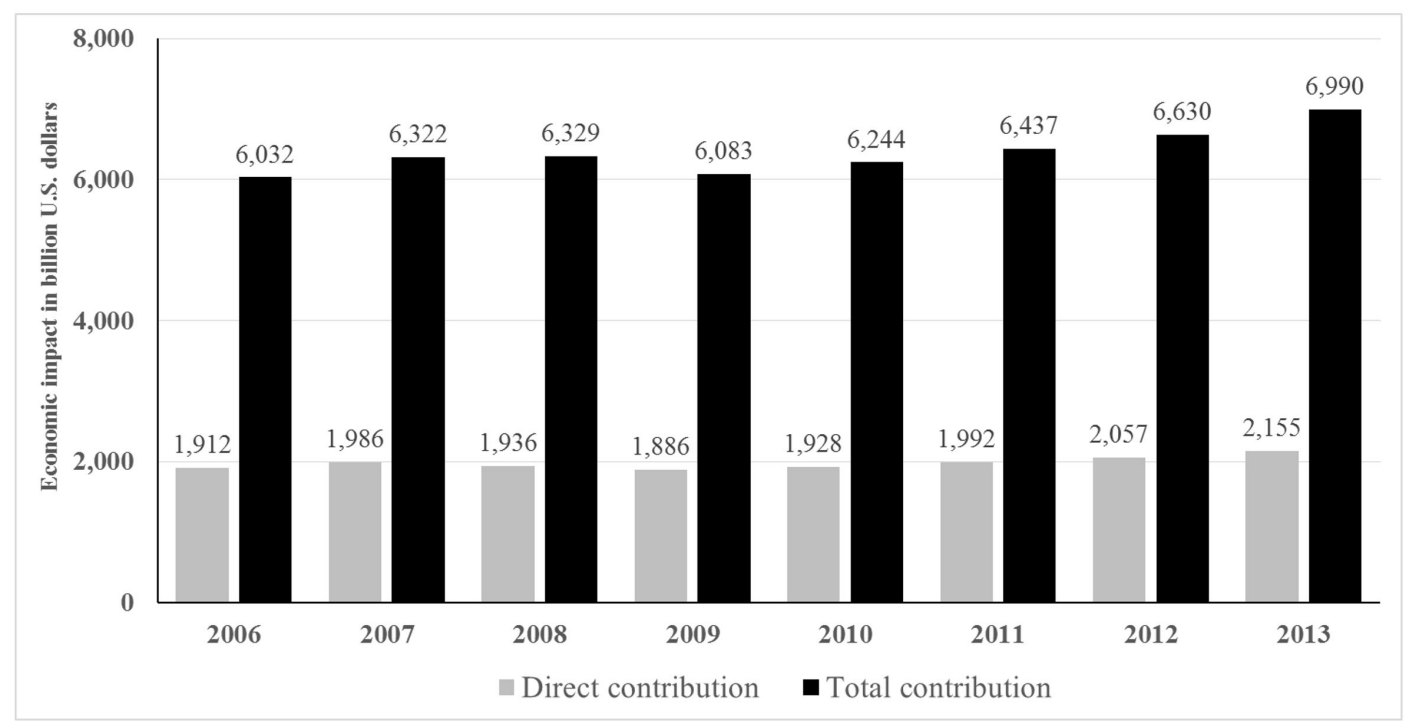

Figure 2: Contribution of travel and tourism to the global economy (in US\$bn)

Source: STATISTA, 2014.

direct and indirect economic contribution (percentage of total) of travel and tourism is estimated to rise from 9.5\% (US\$6,990bn) in 2013 to $10.3 \%$ (US\$10,965bn) in 2024, and is expected to generate $265,855,000$ jobs, $8.9 \%$ of total employment in 2013, rising to $346,901,000$ jobs, $10.2 \%$ of total employment, over the same time period.

Table 1 summarizes the top 10 international tourism destinations tourist arrivals and tourism receipts in 2013 (UNWTO 2014). In 2013, there were 1.087 billion international tourist arrivals worldwide, with a growth of $5.0 \%$ as compared to 1.030 billion in 2012. Also in 2013, there were
1.159 billion international tourism receipts worldwide, with a growth of $7.5 \%$ as compared to 1.078 billion in 2012 .

Since the 21st century, more than one million people have been killed and more than 2 billion others have been directly affected by natural disasters. While recognizing that improved rescue, evacuation, and disease control are crucial to reducing the effects of natural disasters. Furthermore, natural disasters have themselves a tremendous impact on poverty (Guha-Sapir and Santos 2013).

The world tourism industry suffered some severe losses as a result of a series of major international events.

Table 1: Top 10 international tourism destinations tourist arrivals and tourism receipts (2013)

\begin{tabular}{lllll}
\hline Rank & Country & UNWTO Region & International tourism receipts (US\$bn) & International tourist arrivals (Million) \\
\hline 1 & United States & North America & 139.6 & 69.8 \\
2 & Spain & Europe & 60.4 & 60.7 \\
3 & France & Europe & 56.1 & 84.7 \\
4 & China & Asia & 51.7 & 55.7 \\
5 & Italy & Europe & 43.9 & 47.7 \\
6 & Thailand & Asia & 42.1 & 26.5 \\
7 & Germany & Europe & 41.2 & 31.5 \\
8 & United Kingdom & Europe & 40.6 & 31.2 \\
9 & Australia & Oceania & 30.9 & 6.4 \\
10 & Turkey* & Europe & 27.9 & 37.8 \\
\hline
\end{tabular}

\footnotetext{
* Turkey is classified as part of Europe in the UNWTO tourism rankings geolocation scheme.
} Source: UNWTO 2014 
Outlined below is a brief overview of selected major events which have collectively influenced the performance of the tourism industry over the year 2000s. All this events triggered business and consumer uncertainty and falls in tourist arrivals:

- Terrorist attacks in the USA on September 9, 2001.

- SARS virus outbreaks on February 26, 2003.

- Indian Ocean Tsunami on December 26, 2004.

- Tropical Cyclones Hurricane Katrina on August 23, 2005.

- Sichuan Earthquake in China on May 12, 2008.

- Haiti Earthquake on January 12, 2010.

- Japan Earthquake and Tsunami on March 11, 2011.

- Typhoon Haiyan in Philippines on November 8, 2013.

Much of the tourism literature today appreciates the importance of developing tourism 'sustainably'. Whatever the precise meaning of sustainability has an economic dimension alongside its social and environmental dimensions. Sustainable tourism should (UNWTO 2005: 11-12):

1) Make optimal use of environmental resources to conserve natural heritage and biodiversity.

2) Respect the socio-cultural authenticity of host communities, conserve their built and living cultural heritage and traditional values.

3) Ensure viable, providing socio-economic benefits to all stakeholders that are fairly distributed, including stable employment and income-earning opportunities and social services to host communities, and contributing to poverty alleviation.

The various forms of alternative or sustainable tourism such as: 'nature-based tourism', 'ecotourism' and 'cultural tourism'. All tourism activities of whatever motivation - holidays, business travel, conferences, adventure travel and ecotourism - need to be sustainable (UNESCO 2014, September 20). Sustainable tourism development requires the informed participation of all relevant stakeholders. Achieving sustainable tourism is a continuous process and it requires constant monitoring of impacts, introducing the necessary preventive and/or corrective measures whenever necessary.

\section{Insurance and the risk manage- ment framework in tourism industry}

Risk is define as the uncertainty surrounding the outcome of an event, is caused by external or internal vulnerabilities, and an integral and inevitable part of business (Banks 2005: 3). In recent years, the magnitude of disaster/ catastrophic risks has become a major topic of discussion especially in the insurance industry. The tourism sector faces certain challenges, including those related to pricing difficulties, earnings and capital volatility, concentrations, limits of insurability, capacity constraints, and contagion effects. Catastrophes generally results in a large number of individual losses involving many insurance policies as summarized in Table 2 .

For tourism sector, the decision on whether to purchase the insurance coverage is part of the cost/benefit evaluation associated with the risk management decision process (Banks 2005: 72-74). Table 3 summarizes the ten most costly world insurance losses.

On Figure 3, the impact and the average likelihood of environmental risks have marked broad difference than economic, geopolitical and societal risks in 2014. According to Figure 3, the set of risks and their definitions have been continually revised over the years, the comparison still provides some qualitative insight into how global risk perceptions have evolved. Environmental risks have become more prominent since 2011, while health-related risks (pandemics and chronic disease) have become less so.

Considering the size of the icons on Figure 3, while the economic and geopolitical risks occurrence likelihood and impact are below the average, the technological, societal and environmental risks occurrence likelihood and impact are above the average. The highest share in the global risks belongs to environmental risks. Descending sort of environmental risks are extreme weather events, climate change, water crises, natural catastrophes, biodiversity loss and ecosystem and man-made environmental catastrophes.

The risk management discipline has become well established in the business world over the past few decades. Many travel and tourism companies are now accustomed to dealing with the high frequency/low severity financial and operating risks that impact their operations. The same type of risk management framework is applicable to catastrophic risks. In fact, insurance is one of the most efficient and resilient mechanisms available for dealing with low frequency/high severity risks (disasters/catastrophes). But insurance alone is not a sufficient solution. Accordingly, alternative solutions must be factored into the process, including ex ante measures such as loss control/mitigation, and ex post loss financing via reinsurance, capital markets instruments, and public funding. Only when combined is an economy likely to be able to withstand the onset of one or more large disasters (Banks 2005: 13-15). 
Table 2: Natural catastrophes worldwide, $2003-2012^{1}$ (2012 US\$bn)

\begin{tabular}{|c|c|c|c|c|}
\hline Catastrophe type & Number of events & Fatalities & $\begin{array}{l}\text { Overall losses } \\
\text { (US\$bn) }\end{array}$ & $\begin{array}{l}\text { Total Insured losses } \\
\text { (US\$bn) }\end{array}$ \\
\hline Earthquake/tsunami & 657 & 678,400 & 489 & 77.0 \\
\hline Tropical cyclone ${ }^{2}$ & 424 & 65,500 & 539 & 234.0 \\
\hline Severe thunderstorm ${ }^{3}$ & 2,375 & 6,310 & 206 & 126.0 \\
\hline Heatwave/drought & 207 & $132,600^{4}$ & 118 & 22.0 \\
\hline Wildfire & 524 & 1,270 & 27 & 11.0 \\
\hline Winter events ${ }^{5}$ & 401 & 13,000 & 101 & 44.0 \\
\hline River flood/flash flood6 & 2,458 & 54,600 & 274 & 48.0 \\
\hline
\end{tabular}

1. As of July 2013.

2. Includes flooding caused by hurricanes and other tropical cyclones. Includes U.S. National Flood Insurance Program losses.

3. Includes tornadoes.

4. Famine deaths not considered.

5. Includes winter storms, winter damage, and blizzards.

6. Excludes flood damage losses caused by tropical cyclones and hurricanes.

Source: Insurance Information Institute, 07.10.2014.

Table 3. The ten most costly world insurance losses, $1970-2013^{1}$ (US $\$$ millions)

\begin{tabular}{|c|c|c|c|c|}
\hline Rank & Date & Country & Event & $\begin{array}{l}\text { Insured loss } \\
\text { in } 2013 \text { US\$ } \\
\text { millions }^{2}\end{array}$ \\
\hline 1 & Aug. 25, 2005 & $\begin{array}{l}\text { U.S., Gulf of Mexico, Bahamas, North } \\
\text { Atlantic }\end{array}$ & $\begin{array}{l}\text { Hurricane Katrina; storm surge, levee failure, } \\
\text { damage to oil rigs }\end{array}$ & 80,373 \\
\hline 2 & Mar. 11, 2011 & Japan & $\begin{array}{l}\text { Earthquake (Mw 9.0) triggers tsunami: } \\
\text { aftershocks }\end{array}$ & 37,665 \\
\hline 3 & Oct. 24, 2012 & U.S., et al. & Hurricane Sandy, storm surge & 36,890 \\
\hline 4 & Aug. 23, 1992 & U.S., Bahamas & Hurricane Andrew: floods & 27,594 \\
\hline 5 & Sep. 11, 2001 & U.S. & $\begin{array}{l}\text { Terror attacks on WTC, Pentagon and other } \\
\text { buildings }\end{array}$ & 25,664 \\
\hline 6 & Jan. 17, 1994 & U.S. & Northridge earthquake (Mw 6.6) & 22,857 \\
\hline 7 & Sep. 6, 2008 & U.S., Caribbean: Gulf of Mexico et al. & Hurricane Ike; floods, offshore damage & 22,751 \\
\hline 8 & Sep. 2, 2004 & U.S., Caribbean; Barbados et al. & Hurricane Ivan; damage to oil rigs & 17,218 \\
\hline 9 & Jul. 27, 2011 & Thailand & Floods caused by heavy monsoon rains & 16,519 \\
\hline 10 & Feb. 22, 2011 & New Zealand & Earthquake (Mw 6.3), aftershocks & 16,142 \\
\hline
\end{tabular}

1 Property and business interruption losses, excludes life and liability losses. Includes flood losses in the United States insured via the National Flood Insurance Program;

2 Adjusted to 2013 dollars by Swiss Re.

Source: Insurance Information Institute 2014, October 07. 


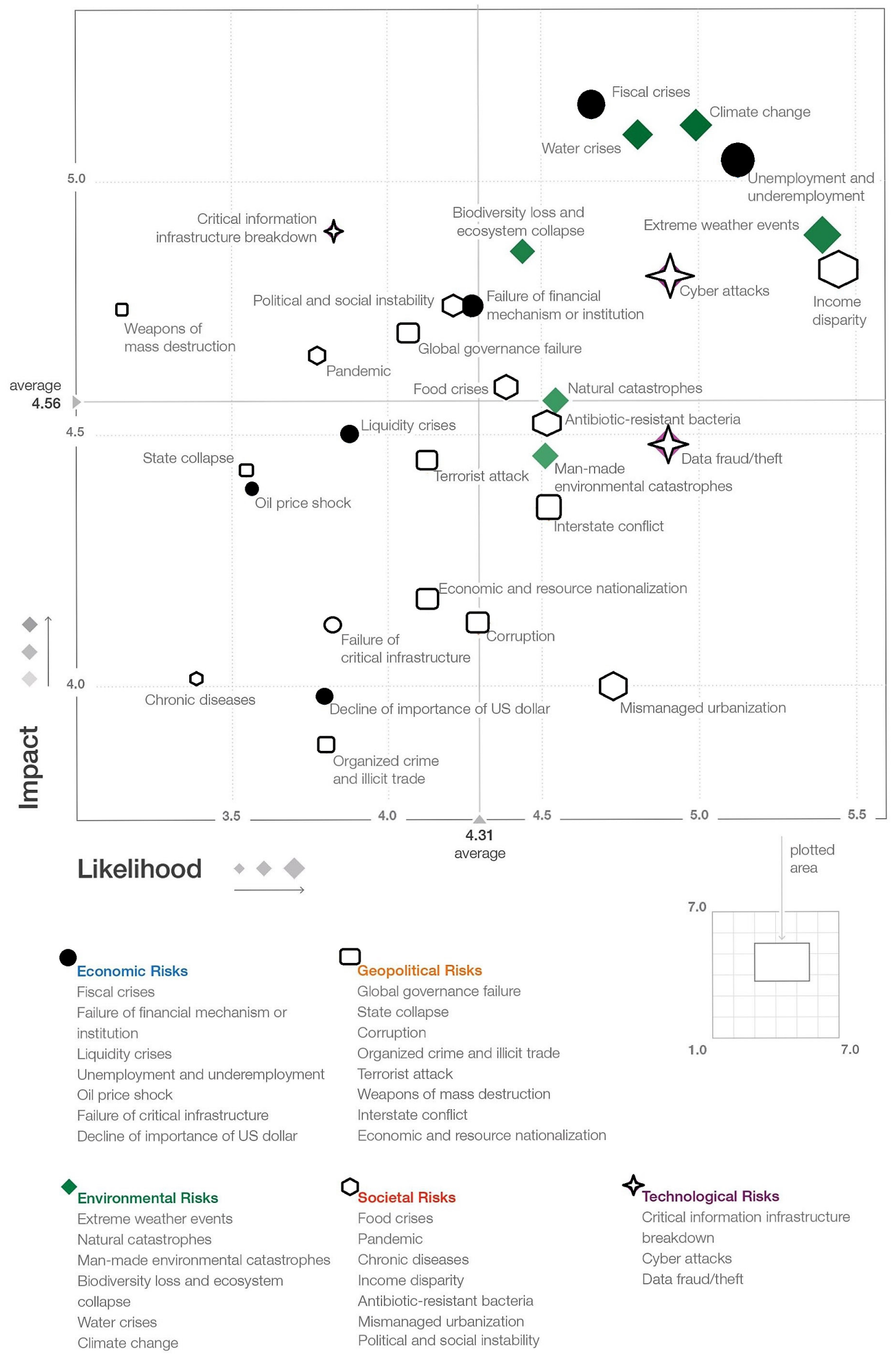

Figure 3: The global risks landscape 2014

Source: World Economic Forum 2014: 16. 
The risk management (the organizational process) and disaster risk management (the multi-agency, community-based process) in the tourism context refers to the planning and implementation of processes directed towards managing the adverse effects of crises and disasters on tourism destinations (Robertson, Kean and Moore 2006: 16). The tourism industry should be involved in both risk management and disaster risk management processes to identify, analyze, evaluate, treat, monitor and review risks to the tourism destinations.

A tourism organization/company manages its risks for three primary reasons: to maximize the value of the company, ensure sufficient liquidity, and solvency. In order to attempt these primary reasons the company must create a risk management program that centers on one or more of three broad strategies: loss control, loss financing, and risk reduction (Banks 2005: 74-80):

i. Loss control; also known as risk mitigation, is typically based on rules, regulations, education, and safety measures, and can be divided into two general categories: avoidance and resistance. Avoidance reduces the financial impact of a hazard by prohibiting expansion in at-risk areas (e.g., no development or construction in certain zones). Resistance, in contrast, tries to reduce the effects of a hazard through safety precautions in at-risk areas (e.g., minimum strength and reinforcement standards for particular buildings).

ii. Loss financing; centers on risk prevention and transfer. Loss financing includes insurance, catastrophe bonds ${ }^{1}$, derivatives and hedging. Hedging is a risk management strategy without buying insurance policies. A tourism company that is exposed to risk of loss from catastrophic risk (e.g., windstorm) can purchase a hedge that provides a payment if a windstorm occurs and creates damage at the tourism facility.

iii. Risk reduction; a third general risk management strategy available to institutions managing exposures, can be split into two components, withdrawal and diversification. Withdrawal refers to the partial or complete abandonment of a business, activity, or location that gives rise to a particular risk exposure. If the tourism facilities are located on an active fault line, it can eliminate the threat of loss from earthquake by closing down the

1 Catastrophe (CAT) Bonds; are event-linked bonds, which trigger payments on the occurrence of a specified event. If the defined catastrophic event occurs, the bond issuer pay claims, and part or all of the interest and principal payments are forgiven. If the defined catastrophic event does not occur, the investors receive their principal plus interest equal to the risk-free rate (e.g., LIBOR), plus a spread above LIBOR. The typical average maturity of CAT bonds is 3 years (Cummins and Mahul 2009: 53). facility and relocating it to another area. The second form of risk reduction relates to diversification, which should achieved by cross-sectoral integration.

Over the past decade, risk management has assumed a much more important role in many firms across different sectors. The risk analysis and management process is broadly the same across most firms (Kunreuther, MichelKerjan and Useem 2013: 7-8).

\section{The tourism risk management process}

Here, the generic risk management process has been adapted to be specific to the needs and context of tourism. The process has been developed for destinations, but the same principles also apply to a tourism business or organization undertaking a risk management process. The following Figure 4 provides an overview of the risk management process which is based upon two enabling activities (communicate and consult, and monitor and review), and five major activities: establish the context, identify risks, analyze risks, evaluate risks and treat risks. (Robertson, Kean and Moore 2006: 24).

Communication and consultation are enabling activities which are fundamental to risk management, and they must be undertaken at each step in the process. Adequate and appropriate communication and consultation will ensure that stakeholders have a sense of the tourism risk management process. It is essential to document all meetings and discussions with stakeholders. Stakeholders in the tourism destination context include: politicians;

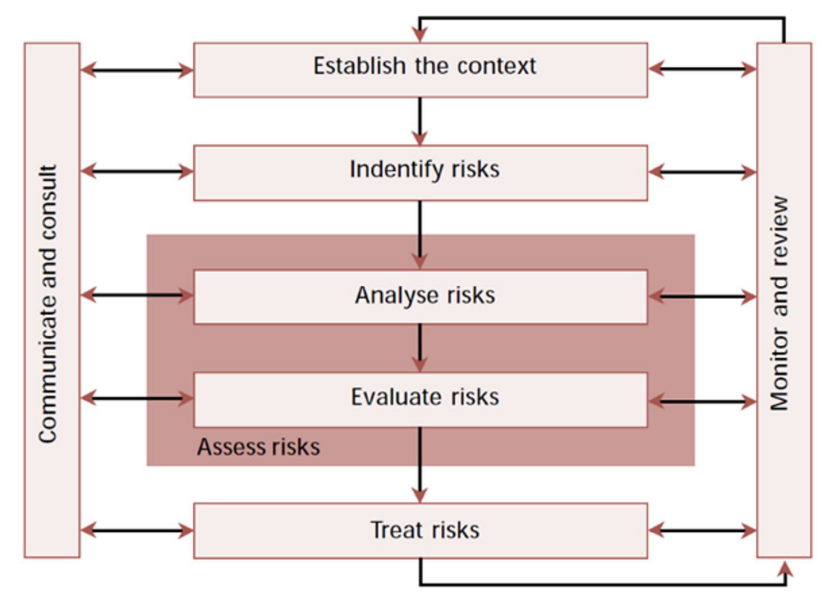

Figure 4: Risk Management Process

Source: Granger, 2000: 20. 
emergency services; tourism organizations and representatives; experts/technical advisors; government officials; airport and port operators; utilities operators (gas, electricity, water); interest groups; and media.

Monitoring and reviewing are enabling activities which are essential so that continual improvements can be achieved and to ensure the currency and relevance of the tourism risk management process. Tourism risk management is an ongoing process with regular monitoring and review of hazards, elements at risk, and the progress, outcomes and efficacy of risk treatment measures.

At the scope of risk management strategy: after establishing coordinated disaster management plans, systems, procedures and processes as a partner with government and community agencies; specify roles and responsibilities of an organization, train personnel, and conduct regular tests of plans, procedures and personnel with subsequent amendment and updating.

Tourism destinations should consider for mainstreaming risk reduction in post-disaster recovery including the use of hazard scenarios to anticipate long term recovery issues. The desired result is a tourism destination that delivers on its promise consistently and has an established reputation for protecting its residents, businesses, and visitors against the effects of natural hazards.

\section{Discussion}

Tourism destinations in every corner of the globe experience a disaster of one form or another at some point in their history. The world tourism industry suffered some severe losses as a result of a series of major international events which were triggered business and consumer uncertainty and falls in tourist arrivals. Many travel and tourism companies are dealing with the financial, operational and also catastrophic risks that impact their operations.

Risk management in the tourism context refers to the planning and implementation of processes directed towards managing the adverse effects of crises and disasters/catastrophes on tourism. Insurance and alternative solutions including ex ante measures such as loss control/ mitigation, and ex post loss financing via reinsurance, capital markets instruments, and public funding must be factored into the risk management process. Only when combined is an economy likely to be able to withstand the onset of one or more large disasters. It should not be forgotten that "natural hazards are not a Disneyland game".

The sustainability of a tourism destination is significantly influenced by its ability to adapt to changing market conditions, use resources efficiently and deliver innovative planning and development strategies. Sustainable tourism holds a long-term view; ethically, socially and culturally adapted, ecologically viable and economically sensible and productive requirements. Achieving sustainable tourism is a continuous process and it requires constant monitoring of impacts, introducing the necessary preventive and/or corrective measures whenever necessary. For the long term sustainability of tourism industry, the primary task should be protecting the natural resources not only for this generation but also for the future generation. Reaching to this target requires tourism planning which based on national, regional, local and sector levels. "Think globally, act locally" is a simple idea or formula which helps to achieve sustainable development in tourism.

\section{References}

[1] Anttila-Hughes, J.K. and Hsiang, S.M. (2011). Destruction, disinvestment, and death: Economic and human losses following environmental disaster. Working paper. URL http:// conference.nber.org/confer//2012/EEEHC12/Hsiang_AntillaHughes.pdf.

[2] Banks, E. (2005). Catastrophic Risk: Analysis and Management. John Wiley \& Sons Ltd.

[3] Cuaresma, J.C., Hlouskova, J. and Obersteiner, M. (2008). Natural disasters as creative destruction? Evidence from developing countries. Economic Inquiry, 46 (2): 214-226.

[4] Cummins, J.D. and Mahul, O. (2009). Catastrophe Risk Financing in Developing Countries Principles for Public Intervention. World Bank.

[5] Granger, K. (2000). An information infrastructure for disaster management in Pacific island countries. Australian Journal of Emergency Management. Autumn. pp.20-32.

[6] Guha-Sapir, D. and Santos, I. (2013). The Economic Impacts of Natural Disasters, Oxford University Press.

[7] Hallegatte, S. and Dumas, P. (2009). Can natural disasters have positive consequences? Investigating the role of embodied technical change. Ecological Economics. 68 (3): 777-786.

[8] Hsiang, S.M. and Jina, A.S. (2014). The Causal Effect of Environmental Catastrophe on Long-Run Economic Growth: Evidence from 6,700 Cyclones. NBER Working Paper, No: 20352.

[9] Insurance Information Institute. (2014, October 07). World, Natural Catastrophes. Retrieved from http://www.iii.org/ fact-statistic/catastrophes-global

[10] Kunreuther, H., Michel-Kerjan, E. and Useem, M. (2013). Corporate Strategies for Managing Catastrophic Risks in the S\&P 500: Linking Intuitive and Deliberative Thinking. The Wharton School, University of Pennsylvania, Interim Report.

[11] Lynham, J. Noy, I. and Page, J. (2012). The 1960 Tsunami in Hawaii: Long Term Consequences of Costal Disaster. University of Hawaìi at Mānoa Department of Economics Working Paper Series, No:12-16. 
[12] Robertson, D., Kean, I. and Moore, S. (2006). Tourism Risk Management: An Authoritative Guide to Managing Crises in Tourism. APEC International Centre for Sustainable Tourism (AICST).

[13] Skidmore, M. and Toya, H. (2002). Do natural disasters promote long-run growth?. Economic Inquiry, 40 (4): 664-687.

[14] STATISTA. (2014, June 10). Retrieved fom http://www.statista. com/statistics/233223/travel-and-tourism--total-economiccontribution-worldwide/

[15] Swiss Re (2014). Natural catastrophes and man-made disasters in 2013: large losses from floods and hail; Haiyan hits the Philippines. Sigma. No:1, p:45.

[16] Tsai, C-H. (2013). Multi-Hazard Risk Assessment and Management in Tourism Industry- A Case Study from the Island of Taiwan. International Journal of Social, Management, Economics and Business Engineering. 7(8).

[17] UNESCO. (2014, September 20). Sustainable Tourism. Retrieved from http://www.unesco.org/education/tlsf/mods/theme_c/ mod16.html?panel=2\#top
[18] UNWTO (2005). Making Tourism More Sustainable - A Guide for Policy Makers.

[19] UNWTO (2014). Tourism Highlights 2014.

[20] World Economic Forum. (2014). Global risks 2014, 9th edition.

[21] WTTC (2010). Travel \& Tourism Economic Impact Report 2010.

[22] WTTC (2014). Travel \& Tourism Economic Impact Report 2014.

[23] Yang, D. (2008). Coping with disaster: The impact of hurricanes on international financial flows, 1970-2002. Advances in Economic Analysis \& Policy. 8 (1): 1903-1903.

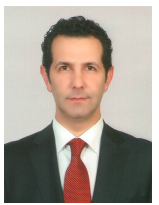

Mert Ural was born on 1972, he received his BA, MA and PhD from Dokuz Eylül University respectively in 1995, 1998 and 2003. His main area of specialization is Financial Economics. He teaches and researches financial institutions, financial derivatives and risk management. He has published many articles, book chapters and a book which entitled "The Performance and Risk Analysis of Mutual Funds”. 